\title{
MANAJEMEN DANA BANK SYARIAH
}

\author{
Nurma Sari \\ Fakultas Syariah dan Ekonomi Islam IAIN Pontianak \\ Email: Nurmasari059@gmail.com
}

\begin{abstract}
Abstrack
The fund given to third party should be well-saved and secured. Therefore, the process of fund pooling and receiving must be based on the rule of Indonesian Bank, DSN, and Islamic bank. Besides, there must be a guarantee of the fund for its safety and cleanliness. Since Islamic bank dominates the use of sharing model, Muämalah Māliah, for profit and risk, it must provide professional investment management. Moreover, Islamic bank should be careful in selecting investment in order to secure client's fund. The main purpose of asset management is to maximize profit, minimize risk, and provide sufficient liquidity. Islamic bank has possible risk as well as conventional bank except interest risk as Islamic bank is according to profit and loss sharing. Bank cannot persuade its clients to invest their money without guarantee for security and withdrawal. Thus, bank must consider the risks that can influence the sum of profit: the assessment of budget and planning profit, company investment effectiveness, asset distribution, and strategy asset management implementation. Asset management strategy must be based on the source of fund and investment characteristics.
\end{abstract}

Key Word: Management, Shari‘ah, and Fund

\begin{abstract}
Abstrak
Setiap penerima dana pihak ketiga (kreditur) merupakan amanah yang harus dijaga keamanan dan kemaslahatannya bagi pemilik dana dan bank. Oleh karena itu, setiap proses penghimpunan dan penerimaan dana harus dilakukan berdasarkan ketentuan peraturan Bank Indonesia, fatwa DSN ataupun peraturan intern bank yang didasarkan pada asas penerimaan, yaitu kebijakan pokok penghimpunan dana bank syariah sebagai lembaga intermediasi dalam mengelola dana masyarakat harus memiliki komitmen dan integritas. Oleh karena itu, setiap proses penghimpunan dana harus mempertimbangkan asas penghimpunan dana yang sehat. Perbankan Syariah lebih mendominasi prinsip bagi hasil berbagi resiko dalam melakukan kegiatan pembiayaan bank syariah menggunakan model pembiayaan muamalah mäliyah. Sehubungan dengan itu bank syariah melakukan pooling dana dana nasabah dan berkewajiban menyediakan manajemen investasi yang professional. Proses pemilihan investasi harus dilakukan dengan seksama karena kesalahan dalam pemilihan bentuk investasi akan membawa akibat bank tidak bisa memenuhi kewajibannya kepada para nasabahnya. Tugas utama manajemen asset adalah memaksimalkan laba meminimalkan risiko dan menjamin tersedianya likuiditas yang cukup. Potensi risiko yang di hadapi oleh bank konvensional juga dihadapi oleh bank syariah, kecuali risiko tingkat bunga karena profit and loss sharing yang menjadi landasan operasionalnya. Sebagaimana diketahui manajemen tidak bisa menarik nasabah untuk mennyimpan uangnya di bank, tanpa adanya keyakinan bahwa dana itu dapat diinvestasikan secara menguntungkan dan dapat dikembalikan ketika dana itu sewaktu waktu di tarik oleh nasabah atau dana
\end{abstract}


tersebut telah jatuh tempo. Oleh karena itu manajemen juga harus secara simultan mempertimbangkan berbagai resiko yang akan berpengaruh pada perubahan tingkat laba yang diperoleh. Manajemen meliputi penilaian terhadap budget dan rencana pendapatan,penilaian kinerja investasi perusahaan lalu memantau distribusi aset bank dan menerapkan strategi manajemen asset. Ruang lingkup teknik manajemen asset bergantung pada sifat dari sumber dana dan sifat investasi atas dana dana tersebut.

Kata Kunci: Manajemen, Bank Syariah, Dana.

\section{Pendahuluan}

Manajemen dalam suatu badan usaha, baik industri, niaga dan jasa, tidak terkecuali jasa perbankan, didorong oleh motif mendapatkan keuntungan (profit). Untuk itu mendapatkan keuntungan yang besar, manajemen haruslah diselenggarakan dengan efisien. Sikap ini harus dimiliki oleh setiap pengusaha dan manager dimanapun mereka berada, baik dalam organisasi bisnis, pelayanan publik, maupun organisasi sosial kemasyarakatan. Perbedaannya hanyalah pada falsafah hidup yang dianut oleh masingmasing pendiri atau manajer badan usaha tersebut. ${ }^{1}$ Demikian juga dalam dunia perbankan, manajemen menjadi sangat penting sebab hal ini akan mempengaruhi kinerja perbankan dan kepercayaan masyarakat.

Masyarakat hanya menginginkan lembaga keuangan yang dapat dipercaya dalam mengembangkan dana yang dimilikinya, khususnya pada perbankan. Selain menginginkan dana yang dikelola oleh orang-orang terpercaya, sehingga mereka merasa aman akan dananya, nasabah juga pasti menginginkan dananya dapat dikembangkan dan memperoleh keuntungan yang maksimal. ${ }^{2}$

Banyak yang meragukan adanya perbankan syariah, sebab mereka beranggapan bahwa sistem perbankan bebas. Bunga adalah suatu yang tidak mungkin dan tidak lazim, dan juga banyak yang mempertanyakan bagaimana bank akan membiayai operasinya. ${ }^{33}$ Pada dasarnya bank syariah berfungsi sebagai agen perantara pemilik dengan modal (nasabah) yang menitipkan uangnya dengan para pengelola usaha atau masyarakat yang membutuhkan dana untuk memenuhi kebutuhan mereka baik kebutuhan konsumtif maupun kebutuhan produktif. Dalam rangka memenuhi kebutuhan

1 Zainul Arifin, Dasar-dasar Manajemen Bank Syariah, (Jakarta: Alvabet, 2002), 102.

2 M. Faruq an-Nabahan, "Sistem Ekonomi Islam: Pilihan Setelah Kegagalan Sistem Kapitalis dan Sosialis”, terj. Muhadi Zainuddin (Yogyakarta: UII Press, 2000), 117.

3 Abdullah Saeed, "Menyoal Bank Syariah: Kritik Atas Intrepretasi Bunga Bank Kaum neo Revivalis", terj. Arif Maftuhin, (Jakarta: Paramadina, 2004), 16. 
masyarakat ini, bank menggunakan prinsip penyertaan dalam rangka pemenuhan permodalan atau dengan prinsip peminjaman untuk pembiayaan.

Bank syariah mempunyai hukum tersendiri yang lain dengan bank konvensional dalam memenuhi kebutuhan-kebutuhan manusia diatas, yakni dengan menggunakan akad-akad hasil (profit loss sharing), sebagai metode pemenuhan kebutuhan permodalan (equty financing) dan akad-akad jual beli untuk memenuhi kebutuhan pembiayaan (deep financing).

Bank syariah adalah bank yang menjalankan bisnis perbankan dengan menganut sistem syariah yang berbasis hukum Islam. Dalam hukum Islam dinyatakan bahwa riba itu haram, sehingga bisnis bank konvensional yang menerapkan system rente atau riba dengan perhitungan Bunga berbunga, baik untuk produk simpanan maupun pinjamannya tidak sesuai dengan hukum Islam.

Bank syariah tidak menerapkan sistem bunga tetapi menerapkan sistem bagi hasil, yaitu sistem pengelolaan dana dalam perekonomian Islam. Perhitungan bagi hasil didasarkan pada mufakat pihak bank bersama nasabah yang menginvestasikan dananya di bank syariah. Besarnya hak nasabah terhadap banknya dalam perhitungan bagi hasil tersebut, ditetapkan dengan sebuah angka ratio atau besaran bagian yang disebut Nisbah.

Pembiayaan bank syariah bagi pengembangan usaha berdasarkan prinsip kemitraan. Dalam prinsip ini, konsep yang diterapkan adalah hubungan antar investor yang harmonis (mutual investor relationship). Adapun dalam sistem konvensional konsep yang diterapkan adalah hubungan debitur dan kreditur yang antagonis (debitor to creditor relationship). ${ }^{6}$

Sudah barang tentu, pengelolaan Bank Syariah dengan demikian perlu suatu manajemen yang dapat memberikan kepercayaan masyarakat dan sesuai dengan ajaran agama. Sebagaimana pendapat Adnan (1999). Bank syariah harus bisa menempatkan posisi 'nasabah' sebagaimana mestinya. Manajemen harus betul-betul dapat memposisikan nasabah sebagai mitra, dan bukan lebih tinggi atau lebih rendah. Manajemen juga harus memahami sisi psikis, bahkan kalau mungkin sisi tauhid nasabah. Sehingga konflik yang bias terjadi akibat perbedaan yang menyolok antara kedua pihak bias dihindari, atau mungkin dimanfaatkan secara positif dan konstruktif. ${ }^{4}$

4 Muhammad Ahyar Adnan, "Beberrapa Issue Disekitar Pengembangan Lembaga Keuangan Berdasarkan Syariah", makalah disajikan dalam Seminar dan Talk Show "Peran Ulama Dalam Sosialisasi Lembaga Keuangan Syariah", 15 Maret 1999. 
Berdasarkan latar belakang ini, dapat dirumuskan satu masalah yaitu bagaimanakah manajemen danan bank syariah?.

\section{Pengertian Manajemen Dana}

Dalam pandangan ajaran Islam, segala sesuatu harus dilakukan secara rapi, benar dan teratur, proses-prosesnya harus diikuti dengan baik.Sesuatu tidak boleh dilakukan secara asal-asalan. Hal ini merupakan prinsip utama dalam ajaran islam. Sesuai dengan Hadis Nabi saw: "sesungguhnya Allah sangat mencintai orang yang jika melakukan pekerjaan, dilakukan secara itqān (tepat, terarah, jelas dan tuntas)." (HR. Thabrani).

Melakukan pekerjaan dengan benar, rapi dan benar itulah pokok dari manajemen, dan merupakan suatu yang di syariatkan dalam ajaran Islam. ${ }^{5}$ Manajemen secara umum berarti suatu aktifitas khusus yang mencakup kepemimpinan. Pengarahan, pengembangan personal, perencanaan dan pengawasan terhadap pekerjaan-pekerjaan yang berkenaan dengan unsur-unsur pokok dalam suatu proyek, agar hasil-hasil yang ditargetkan dapat tercapai dengan cara efektif dan efisien. ${ }^{6}$ Dalam Islam, manajemen terdiri dari beberapa prinsip yang harus ada di dalamnya, yaitu prinsip keadilan, amanah dan tanggung jawab.

Demikian juga manajemen dalam Perbankan Islam, sebab lembaga keuangan merupakan lembaga yang dibangun atas dasar kepercayaan, sehingga manajemen yang baik sangat diperlukan, termasuk di dalamnya manajemen dana.

Manajemen Dana Bank Syariah adalah upaya yang dilakukan oleh lembaga bank syariah dalam mengelola atau mengatur posisi dana yang diterima dari aktifitas funding untuk disalurkan kepada aktifitas financing. Dengan harapan bank yang bersangkutan tetap mampu memenuhi kriteria-kriteria likuiditas, rentabilitas dan solvabilitasnya. ${ }^{7}$

\section{Tujuan dan Pengelolaan Manajemen Dana}

Sebagaimana hal nya dengan bank konvensional, Bank Syariah juga mempunyai peran sebagai lembaga perantara (intermediary) antara satuan-satuan kelompok masyarakat atau unit-unit ekonomi yang mengalami kelebihan dana atau surplus unit dengan unit-unit lainyang mengalami kekurangan dana difisit unit. Melalui bank

5 Didin Hafifuddin, Manajemen Syariah (Jakarta: Gema Insani Press,2003), 2.

6 Muhammad, Manajemen Bank Syariah (Yogyakarta: UPP AMP YKPN,2002), 148.

7 Ibid, 228. 
kelebihan dana-dana tersebut dapat disalurkan kepada pihak-pihak yang memerlukan dan memberikan manfaat kepada kedua belah pihak. ${ }^{8}$

Upaya pencapaian keuntungan yang setinggi-tingginya (profit maximation) adalah tujuan yang biasa di canangkan oleh bank komersial, berbeda dengan tujuan ini, Bank Islam berdiri untuk menggalakkan, memelihara, serta mengembangkan jasa serta produk perbankan yang berazaskan syari'at Islam. ${ }^{9}$ Demikian juga dalam pengelolaan dana, diperlukan manajemen dana dengan tujuan yang sesuai dengan ajaran syariat Islam. Secara umum dapat digambarkan bahwa tujuan manajemen dana adalah: ${ }^{13}$

1. Memperoleh profit yang optimal

2. Menyediakan aktiva cair dan kas yang memadai

3. Menyimpan cadangan

4. Mengelola kegiatan-kegiatan lembaga ekonomi dengan kebijakan yang pantas bagi seseorang yang bertindak sebagai pemelihara dana-dana orang lain.

5. Memenuhi kebutuhan masyarakat akan pembiayaan

Bank syariah dirancang untuk melakukan fungsi pelayanan sebagai lembaga keuangan bagi para nasabah dan masyarakat. Untuk itu, Bank Syariah harus mengelola dana yang dapat digolongkan sebagai berikut: ${ }^{10}$

1. Kekayaan Bank Syariah dalam bentuk :

a. kekayaan yang menghasilkan (aktiva produktif) yaitu pembiayaan untuk debitur serta penempatan dana di bank atau investasi lain yang menghasilkan pendapatan.

b. Kekayaan yang tidak menghasilkan, yaitu kas dan investaris (harta tetap)

2. Modal Bank Syariah, berasal dari :

a. Modal sendiri, yaitu simpanan pendiri (modal), cadangan dan hibah, infaq atau shadaqah.

b. Simpanan atau hutang dari pihak lain.

3. Pendapatan usaha keuangan Bank Syariah berupa bagi hasil atau mark up dari pembiayaan yang diberikan dan biaya administrasi serta jasa tabungan bank syariah di bank.

4. Biaya yang harus dipikul oleh Bank Syariah, yaitu biaya operasi, biaya gaji, manajemen, kantor dan bagi hasil simpanan nasabah penabung.

Untuk mengetahui hal tersebut pihak bank syariah dapat melakukan kegiatan manajemen sebagai berikut :

8 Zainul Arifin, Dasar-dasar..., 51.

9 Tim Pengembangan Perbankan Syariah, Institut Bankir Indonesia, Konsep, Produk, dan Implementasi Operasional Bank Syariah (Jakarta: Djambatan, 2001), 23. 
1. Rencana keuangan(budgeting)

2. Pemelihara likuiditas

3. Pengawasan efisiensi

4. Rentabilitas

5. Aktiva produktif (pembiayaan)

\section{Sumber Dana Bank Syariah}

Bank Syariah sebagai suatu lembaga keuangan yang salah satu fungsinya adalah menghimpun dana masyarakat, harus memiliki suatu sumber untuk menghimpun dana sebelum disalurkan kemasyarakat kembali. ${ }^{16}$ Sumber dana Bank Syariah terdiri dari. ${ }^{17}$

1. Modal inti (core capital). Modal ini adalah dana modal sendiri yaitu dana yang berasal dari pemegang saham bank yakni pemilik bank. Pada umumnya dana modal inti terdiri dari :

a. Modal yang disetor oleh para pemegang saham. Sumber utama dari modal perusahaan adalah saham. Sumber dana ini hanya akan timbul apabila pemilik menyertakan dananya pada bank melalui pembelian saham dan untuk penambahan dana berikutnya dapat dilakukan oleh bank dengan mengeluarkan dan menjual tambahan saham.

b. Cadangan, yaitu sebagian laba bank yang tidak dibagi, yang disisihkan untuk menutup timbulnya resiko kerugian dikemudian hari.

c. Laba ditahan, yaitu sebagian laba yang seharusnya dibagi kepada para pemegang saham, tetapi oleh para pemegang saham sendiri (melalui rapat Umum Pemegang Saham) diputuskan untuk ditanam kembali dalam bank. Laba ditahan ini juga merupakan cara untuk menambah dana modal lebih lanjut.

2. Sumber-sumber Penghimpunan Dana

Pada dasarnya, bank mempunyai empat alternatif menghimpun dana untuk kepentingan usahanya, yaitu:

\section{a. Dana sendiri}

Meskipun proporsi dana sendiri ini relatif kecil apabila dibandingkan dengan total dan yang dihimpun ataupun total aktivanya, dana sendiri ini tetap merupakan hal yang penting untuk kelangsungan usahanya. Begitu pentingnya proporsi dana sendiri ini dibuktikan dengan adanya ketentuan dan bank sentral yang mengatur proporsi minimal modal sendiri dibandingkan dengan total nilai Aktiva Tertimbang Menurut Risiko (ATMR). Proporsi ini lebih dikenal dengan Capital Adequacy Ratio CAR. Di Indonesia, dalam kondisi normal, BI 
menetapkan CAR minimum sebesar 8\%, dan secara gradual ditingkatkan hingga mencapai $12 \%$. Apabila CAR suatu bank terlalu rendah, kemampuan bank tersebut untuk bertahan pada saat mengalami kerugian juga rendah.

Modal sendiri akan cepat habis untuk menutup kerugian, dan ketika kerugian telah melebihi modal sendiri, kemampuan bank tersebut untuk memenuhi kewajiban kepada masyarakat menjadi sangat diragukan. Demikian juga, kemampuan untuk mengembalikan dana simpanan masyarakat juga menjadi diragukan. Penurunan kemampuan ini akan menurunkan tingkat kepercayaan masyarakat di bank tersebut. Selanjutnya, penurunan tingkat kepercayaan terhadap suatu bank sangat membahayakan kelangsungan usaha bank itu. Seperti halnya badan usaha lain, perhimpunan dana sendiri antara lain dapat berupa modal disetor, dana dan penjualan saham di bursa efek, akumulasi laba ditahan, cadangan-cadangan, dan agio saham.

Berdasarkari UU No. 7 tahun 1992, Bank Umum dapat melakukan mobilisasi dana dengan cara melakukan emisi saham dan obligasi melalui bursa efek di Indonesia.

b. Dana dan deposan

Pada dasarnya, sumber dana dan masyarakat dapat berupa giro (demand deposit), tabungan (saving deposit), dan deposito berjangka (time deposit) yang berasal dari nasabah perorangan atau badan.

1) Giro

Rekening giro atau checking account adalah simpanan yang penarikannya dapat dilakukan setiap saat dengan menerbitkan cek untuk penarikan tunai atau bilyet giro untuk pemindahbukuan.Cek atau bilyet giro dapat digunakan oleh pemiliknya sebagai alat pembayaran.Untuk itu, pemegang rekening giro memperoleh buku cek dan bilyet giro. Karena sifat penarikannya yang dapat dilakukan setiap saat, sumber dana dan rekening giro ini merupakan sumber dana jangka pendek yang jumlahnya relatif lebih dinamis atau berfluktuasi dari waktu ke waktu. Bagi nasabah pemegang rekening giro, sifat penarikan tersebut sangat membantu dalam membiayai kegiatan mereka secara lebih efisien.Nasabah dapat melakukan pembayaran sewaktu-waktu tanpa harus berisiko meng- 
gunakan uang tunai dalam jumlah besar, tanpa harus datang langsung ke bank, dan tanpa harus menunggu tanggal jatuh tempo tertentu.

Cek merupakan perintah tidak bersyarat kepada bank untuk membayar sejumlah uang tertentu pada saat penyerahannya atas beban rekening penarik cek: Cek dapat ditarik atau diterbitkan oleh pemegang rekening giro (giran) atas unjuk atau atas nama dan tidak dapat dibatalkan oleh penarik, kecuali cek tersebut dinyatakan hilang atau dicuri dengan bukti dari kepolisian Jangka waktu pengunjukan agar mendapatkan pembayaran dan bank atas cek tersebut adalah selama 70 hari sejak tanggal pengunjukanya.

Bilyet giro pada dasarnya merupakan perintah kepada bank untuk memindahbukukan sejumlah berbentu uang atas beban rekening penarik pada tanggal tertentu kepada pihak yang tercantum dalam bilyet giro tersebut dan bilyet giro dapat dibatalkan secara sepihak oleh penarik disertai dengan alasan pembatalan.

Jasa giro merupakan suatu imbalan yang diberikan oleh bank kepada giran atas sejumlah saldo gironya yang mengendap di bank.Jasa giro ini relatif lebih kecil apabila dibandingkan dengan simpanan dalam bentuk tabungan dan deposito berjangka karena tujuan seorang nasabah memegang rekening giro bukan memperoleh imbalan semacam bunga simpanan tersebut, melainkan untuk memperoleh berbagai fasilitas yang dimiliki oleh rekening giro. Fasilitas ini adalah adanya alat pembayaran yang efisien berupa cek dan bilyet giro serta penarikan yang dapat dilakukan sewaktu-waktu. Oleh karena itu, giran umumnya adalah pengusaha atau pihak yang memiliki kegiatan yang membutuhkan alat pembayaran dalam bentuk cek dan bilyet giro. Apabila ditinjau dari sudut pandang bank, dana yang berasal dari giro ini merupakan dana murah, dalam pengertian, bank harus memberikan jasa giro yang relatif lebih rendah dibandingkan bunga simpanan dalam bentuk tabungan dan deposito berjangka.

2) Deposito berjangka 
Deposito berjangka adalah simpanan yang penarikannya hanya dapat dilakukan pada waktu tertentu sesuai tanggal yang diperjanjikan antara deposan dan bank. Mengingat simpanan ini hanya dapat dicairkan pada saat jatuh temponya oleh pihak yang namanya tercantum dalam bilyet deposito sesuai tanggal jatuh temponya, deposito berjangka ini merupakan simpanan atas nama. Apabila deposan menghendaki agar deposito berjangkanya dapat diperpanjang secara otomatis, pihak bank dapat memberikan fasilitas ARO atau Automatic Roll-Over atas deposito berjangka tersebut.

Kelebihan deposito berjangka ini adalah dapat ditarik tunai setiap jangka waktu tertentu ataupun ditransfer ke rekening deposan. Nasabah biasanya membuka rekening tabungan untuk menampung bunga atas deposito tersebut dan menampung dana deposito yang telah jatuh tempo dan tidak diperpanjang lagi. Bank-bank tertentu juga memberikan fasilitas agar bunga deposito yang tidak ditarik oleh pemiliknya dapat ditambahkan dalam simpanan pokok deposito sehingga nilai deposito berjangkanya bertambah besar. Pada dasarnya, sebelum jatuh tempo, simpanan ini tidak dapat ditarik, tetapi apabila pihak deposan tetap menginginkan penarikan sebelum jatuh tempo, biasanya bank mengenakan denda atau biaya administrasi atas penarikan tersebut.

Kelebihan dana deposito ini bagi bank adalah bank mempunyai kepastian tentang jangka waktu dana itu akan ditarik, sehingga pihak bank dapat mengantisipasi kapan harus menyediakan dana dalam jumlah tertentu. Kelebihan ini tidak dimiliki oleh simpanan dalam bentuk giro dan tabungan. Sebagai konsekuensi dan kelebihan tersebut, bank harus membayar dana ini dengan tingkat bunga yang relatif lebih besar dibandingkan dengan simpanan dalam bentuk lain.Dengan kata lain, simpanan dalam bentuk deposito berjangka tidak bisa disebut sebagai sumber penghimpunan dana bagi bank yang murah.

Pada sisi deposan, nasabah lebih menyukai menyimpan kelebihan dananya dalam bentuk deposito berjangka sesuai jangka waktu yang 
diinginkan karena simpanan ini menawarkan tingkat bunga yang relatif lebih tinggi.

3) Tabungan

Tabungan adalah simpanan yang penarikannya hanya dapat dilakukan dengan syarat tertentu yang disepakati, dan tidak dengan cek atau bilyet giro atau alat lain yang dapat dipersamakan dengan itu. Cara penarikan rekening tabungan yang paling banyak digunakan saat ini adalah dengan buku tabungan, cash card atau kartu ATM, dan debet card. Persaingan ketat dalam penghimpunan dana melalui tabungan antarbank telah banyak memunculkan cara baru untuk menarik nasabah tabungan. Cara-cara tersebut antara lain hadiah atas tabungan, fasilitas asuransi atas tabungan, fasilitas kartu ATM, dan fasilitas debet card.

Ditinjau dari segi keluwesan penarikan dana, simpanan dalam bentuk tabungan berada di tengah-tengah antara giro dan deposito berjangka. Tabungan dapat ditarik dengan caracara dan dalam waktu yang relatif lebih fleksibel dibandingkan dengan deposito berjangka, tetapi masih lebih fleksibel apabila dibandingkan dengan rekening giro.

Sebagai konsekuensinya, besarnya bunga yang diberikan atas saldo tabungan ini pun berada di tengah-tengah antara giro dan deposito berjangka. Ditinjau dari sisi bank, penghimpunan dana melalui tabungan termasuk lebih murah daripada deposito, tetapi lebih mahal dibandingkan giro.

4) Cara lain penghimpunan dana dan deposan

Persaingan yang ketat dalam penghimpunan dana antar bank telah memunculkan produk-produk baru dalam penghimpunan dana. Produkproduk baru tersebut antara lain:

a) Sertifikat deposito merupakan hasil pengembangan dana deposito berjangka. Sertifikat deposito adalah deposito berjangka yang bukti simpanannya dapat diperjualbelikan.Agar simpanan ini dapat diperjualbelikan dengan mudah, penarikan pada saat jatuh tempo dapat dilakukan atas unjuk, sehingga siapa pun yang memegang 
bukti simpanan tersebut dapat menguangkannya pada saat jatuh tempo. Hal lain yang menjadi ciri dan sertifikat deposito adalah dalam hal pembayaran bunganya. Apabila deposito berjangka bunga dibayarkan setelah dana mengendap, bunga sertifikat deposito ini dibayarkan di muka, yaitu pada saat nasabah menempatkan dananya dalam bentuk deposito.

b) Deposit on call, yaitu simpanan yang penarikannya hanya dapat dilakukan dengan pemberitahuan lebih dahulu dalam jangka waktu tertentu sesuai dengan kesepakatan antara pihak bank dan nasabah. Semakin besar dana yang akan ditarik, semakin lama pula jangka waktu pemberitahuan sebelumnya yang diinginkan oleh pihak bank. Tingkat bunga biasanya ditetapkan lebih rendah daripada tingkat bunga deposito berjangka dan lebih tinggi daripada jasa giro. Deposit on call biasanya digunakan oleh nasabah yang tidak setiap saat perlu menarik dananya dan keperluan penarikan dana itu dapat diprediksi oleh nasabah dalam jangka waktu tertentu.

c) Rekening giro terkait tabungan. Ditinjau dari tingkat bunganya, nasabah lebih menyukai tabungan, tetapi ditinjau dari cara penarikannya, nasabah lebih menyukai rekening giro. Nasabah cenderung untuk mempertahankan saldo rekening giro serendah mungkin sepanjang dapat memenuhi kebutuhan transaksinya. Setiap kali saldo rekening giro ini menjadi terlalu kecil, nasabah akan memindahkan sebagian dana tabungannya ke rekening giro dan sebaliknya apabila saldo rekening giro ini dipandang lebih besar daripada kebutuhan transaksinya, nasabah akan memindahkan sebagian saldo rekening giro ke rekening tabungannya.

Berdasarkan pemahaman atas masalah yang dihadapi nasabah tersebut, bank memberikan fasilitas khusus berupa pemindahan sebagian saldo rekening tabungan ke rekening giro. Fasilitas ini memungkinkan nasabah menikmati 
bunga yang lebih tinggi, yaitu bunga tabungan, tetapi tetap dapat menikmati kelebihan fasilitas rekening gironya. Penyetoran oleh nasabah selalu dimasukkan rekening tabungan, sementara jika nasabah menarik cek atau bilyet giro dan ternyata saldo rekening giro tidak mencukupi, pihak bank akan melakukan pemindahbukuan dari tabungan ke rekening giro. Pihak bank dapat melakukan pemindahbukuan setelah mendapatkan surat kuasa dari nasabah.

c. Dana pinjaman

Dana pinjaman yang diperoleh bank dalam rangka menghimpun dana antara lain dapat berupa sebagai berikut

\section{1) Call money}

Call money merupakan sumber dana yang dapat diperoleh bank berupa pinjaman jangka pendek dan bank lain melalui interbank call money market. Sumber dana ini sering digunakan oleh bank untuk memenuhi kebutuhan dana mendesak dalam jangka pendek, seperti bila terjadi kalah kliring atau adanya rush. Dana dan call money berjangka waktu relatif pendek,yaitu satu hari atau overnight sampai dengan 180 hari, dan tingkat bunganya berfluktuasi serta sangat dipengaruhi oleh permintaan dan ketersediaan dana di pasar pada suatu saat Apabila Iikuiditas perbankan secara umum di suatu area sedang sulit, tingkat bunga call money bisa menjadi sangat tinggi, jauh lebih tinggi daripada tingkat bunga pinjaman umum. Call money dapat juga dimanfaatkan oleh bank yang sedang mengalami kelebihan likuiditas untuk menyalurkan dananya dalam jangka pendek, sehingga kelebihan likuiditas tersebut menjadi dana yang produktif menghasilkan penerimaan bagi bank.

2) Pinjaman antar bank

Kebutuhan pendanaan kegiatan usaha suatu bank dapat juga diperoleh dari pinjaman jangka pendek dan menengah, dan bank lain. Berbeda dengan call money seperti telah diuraikan pada bagian sebelumnya, pinjaman ini dilakukan bukan untukmemenuhi kebutuhan dana mendesak dalam jangka pendek, melainkan untuk memenuhi suatu kebutuhan dana yang lebih terencana dalam rangka pengembangan usaha atau meningkatkan penerimaan bank.

3) Kredit Likuiditas Bank Indonesia (KLBI)

Sesuai dengan namanya, Kredit Likuiditas Bank Indonesia adalah kredit 
yang diberikan oleh Bank Indonesia, terutama kepada bank yang sedang mengalami kesulitan likuiditas. Masalah kesulitan likuiditas ini bisa terjadi karena kalah kliring atau adanya rush penarikan dana oleh nasabah suatu bank. Untuk kepentingan mempertahankan kepercayaan masyarakat terhadap sektor perbankan secara umum, BI akan berusaha memberikan bantuan likuiditas kepada bank tersebut sepanjang masih memungkinkan untuk ditolong. Pada masa sebelum deregulasi perbankan, dana ini banyak digunakan BI untuk membiayai proyek atau program pemerintah tertentu dan bukan untuk mengatasi kesulitan likuiditas suatu bank. Setelah adanya deregulasi, penggunaan dana KLBI untuk keperluan non-kesulitan likuiditas secara bertahap mulai dikurangi.

d. Sumber dana lain

Selain berasal dari dana sendiri, dana deposan, dan dana pinjaman, sumber penghimpunan dana dapat juga berasal dari sumber-sumber lain yang tidak dapat digolongkan dalam jenis dana di atas. Sumber dana yang lain selalu berkembang sesuai dengan perkembangan usaha perbankan dan perekonomian secara umum. Sumber-sumber tersebut antara lain sebagai berikut.

1) Setoran jaminan

Setoran jaminan atau sering disingkat menjadi storjam merupakan sejumlah dana yang wajib diserahkan oleh nasabah yang menerima jasa jasa tertentu dari bank. Nasabah tersebut menyerahkan storjam karena jasa-jasa yang diberikan oleh bank mengandung risiko finansial tertentu yang ditanggung oleh pihak bank. Dengan adanya storjam, nasabah diharapkan mempunyai komitmen untuk berperilaku positif sehingga pada kemudian hari, bank tidak harus mengalami kerugian karena menanggung risiko yang timbul. Storjam ini juga dibutuhkansebagai dana untuk menutup sebagian kerugian bank yang mungkin timbul akibat terjadinya risiko. Jasa-jasa bank yang biasanya memerlukan storjam, antara lain adalah Letter of Credit (LC) dan Bank Garansi (BG). Penjelasan lebih lengkap mengenai LC dan BG dapat dibaca pada bagian mengenai "Penggunaan Dana". Dana storjam yang tersimpan di bank tidak menimbulkan kewajiban bagi bank untuk memberikan imbal jasa berupa bunga, sehingga dana ini merupakan dana murah yang dapat 
digunakan bank untuk kegiatan usahanya. Perlu diingat bahwa dana storjam ini biasanya hanya akan mengendap di bank untuk jangka pendek dan menengah sesuai jangka waktu jasa yang diberikan oleh bank. Dengan demikian, penggunaan dana storjam ini harus disesuaikan dengan jangka waktu storjam.

\section{2) Dana transfer}

Salah satu jasa yang diberikan bank adalah pemindahan dana. Pemindahan dana bisa berupa pemindahbukuan antara rekening, dana uang tunai ke suatu rekening, atau dan suatu rekening untuk kemudian ditarik tunai. Sebelum dana transfer ini ditarik oleh penerima transfer atau selama masih mengendap di bank, dana ini dapat digunakan oleh bank untuk mendanai kegiatan usahanya. Dana ini jelas hanya akan mengendap di bank untuk jangka waktu yang sangat singkat akan tetapi, sumber dana ini digolongkan sebagai sumber dana yang tidak berbiaya. Dana transfer yang tersimpan di bank tidak menimbulkan kewajiban bagi bank untuk memberikan imbal jasa berupa bunga, sehingga dana ini merupakan dana murah bagi bank. Mengingat dana transfer biasanya hanya mengendap dalam waktu singkat, dana ini termasuk dana jangka pendek.

\section{3) Surat berharga pasar uang}

Salah satu akibat adanya serangkaian paket deregulasi perbankan sejak tahun 1980-an adalah diperkenalkannya Surat Berharga Pasar Uang (SBPU) sebagai salah satu instrumen yang digunakan pihak bank untuk menghimpun dana. SBPU merupakan surat-surat berharga jangka pendek yang dapat diperjualbelikan dengan cara di diskonto oleh Bank Indonesia.Ketika suatu bank mempunyai kelebihan likuiditas, bank tersebut dapat membeli berbagai macam SBPU, dan menjualnya kembali pada saat mengalami kekurangan likuiditas.

4) Diskonto Bank Indonesia.

Fasilitas diskonto adalah penyediaan dana jangka pendek oleh BI dengan cara pembelian promes yang diterbitkan oleh bank-bank atas dasar diskonto. Fasilitas diskonto ini merupakan upaya terakhir bank dan merupakan bantuan Bank Sentral sebagai lender of last resort. Fasilitas diskonto ini dapat 
dibagi dua, yaitu Fasilitas diskonto I dan Fasilitas Diskonto II. Fasilitas Diskonto I disediakan dalam rangka memperlancar pengaturan dana bank sehari-hari, sedangkan Fasilitas Diskonto II diberikan untuk memudahkan bank dalam menanggulangi kesulitan pendanaan karena rencana pengerahan dana tidak sesuai dengan penarikan kredit jangka menengah atau panjang oleh nasabah (mismatch). ${ }^{\mathrm{i}}$

5) Kuasi ekuitas (mud̄ārabah account).

Bank menghimpun dana berbagi hasil atas dasar muḍārabah, yaitu akad kerjasama antara pemilik dana (șâhib al mâl) dengan pengusaha (mudāarib) untuk melakukan suatu usaha bersama, dan pemilik dana tidak boleh mencampuri pengelolaan bisnis sehari-hari. Keuntungan yang diperoleh dibagi antara keduanya dengan perbandingan (nisbah) yang telah disepakati sebelumnya. Kerugian financial menjadi beban pemilik dana sedangkan pengelola tidak memperoleh imbalan atas usaha yang dilakukan. Berdasarkan prinsip ini, dalam kedudukannya sebagai mudārib, bank menyediakan jasa bagi para investor, berupa: Rekening Investasi Umum, rekening investasi khusus, dan rekening tabungan muḍa ārabah.

6) Titipan (wadīah) atau simpanan tanpa imbalan.

Dana titipan adalah dana pihak ketiga yang dititipkan pada bank yang umumnya berupa giro atau tabungan. Pada umumnya motivasi utama orang menitipkan dana pada bank adalah untuk keamanan dana mereka dan memperoleh keluasaan untuk menarik kembali dananya sewaktu-waktu. Wadīah dikembangkan dalam bentuk giro wadīah dan rekening tabungan wadīah.

a) Rekening Giro Wadīah

Bank Islam dapat memberikan jasa simpanan giro dalam bentuk rekening wadīah. Dalam hal ini bank Islam menggunakan prinsip wadīah yad damanah.Dengan prinsip ini bank sebagai custodian harus menjamin pembayaran kembali nominal simpanan wadīah. Dana tersebut dapat digunakan oleh bank untuk kegiatan komersial dan bank berhak atas pendapatan yang diperoleh dari pemanfaatan harta titipan tersebut dalam kegiatan komersial. Pemilik simpanan dapat menarik kembali simpanannya sewaktu-waktu, baik sebagian maupun seluruhnya. Bank 
tidak boleh menjanjikan imbalan atau keuntungan apapun kepada rekening wadīah, dan sebaliknya pemegang rekening juga tidak boleh mengharapkan atau meminta imbalan atau keuntungan atas rekening wadīah. Namun demikian atas kehendak bank sendiri, dapat memberikan ${ }^{11}$ imbalan berupa bonus (hibah) kepada pemilik dana.

b) Rekening Tabungan Wadīah

Prinsip wadiah yad damanah juga dipergunakan oleh bank dalam mengelola jasa tabungan yaitu simpanan dari nasabah yang memerlukan jasa penitipan dana dengan tingkat keleluasaan tertentu untuk menarinya kembali. Bank memperoleh ijin dari nasabah untuk menggunakan dana tersebut selama mengendap di bank. Nasabah dapat menarik sebagian atau seluruh saldo simpanannya sewaktu-waktu atau sesuai dengan perjanjian yang telah disepakati.Bank menjamin pembayaran kembali simpanan mereka. Semua keuntungan atas pemanfaatan dana tersebut adalah milik bank. Tetapi atas kehendaknya sendiri bank dapat memberikan imbalan keuntungan yang berasal dari sebagian keuntungan. ${ }^{18}$

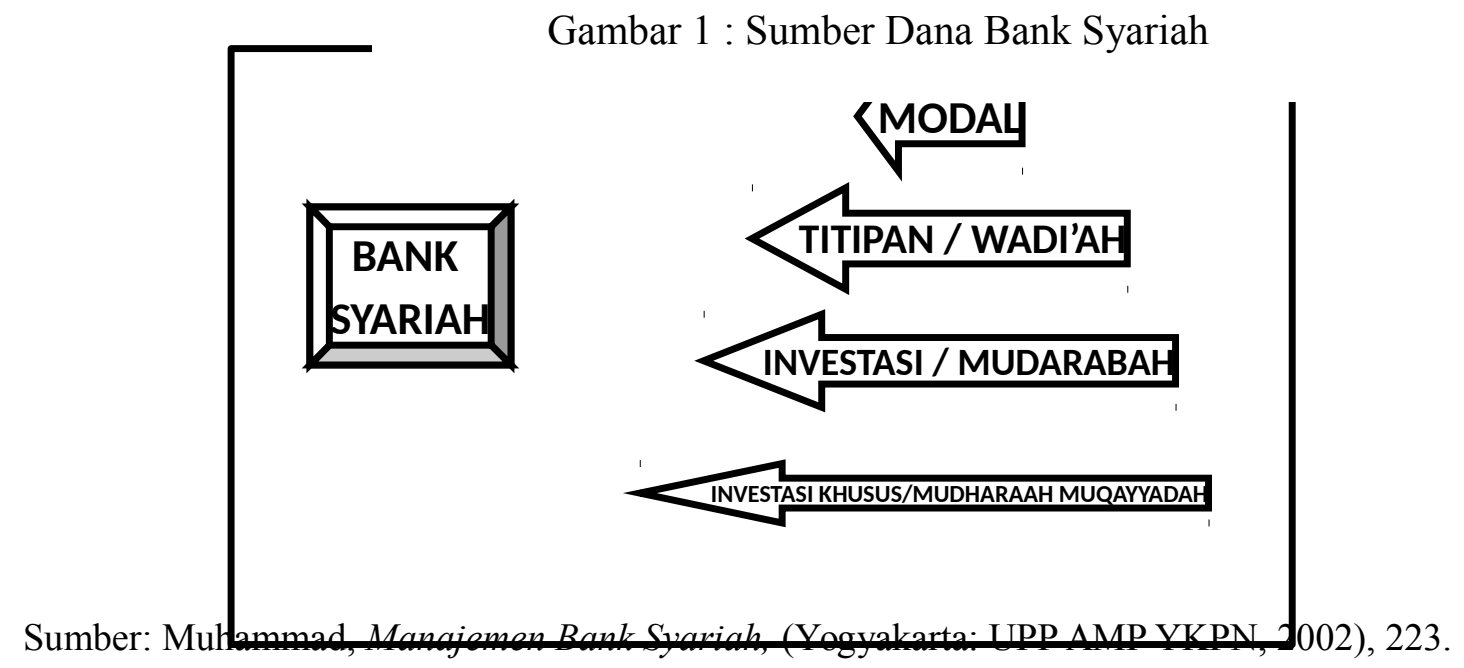

\section{Penggunaan Dana Bank}

Setelah dana bank ketiga telah dikumpulkan oleh bank, maka sesuai dengan fungsinya sebagai intermediary, bank berkewajiban menyalurkan dana tersebut untuk pembiayaan. Dalam hal ini, bank harus mempersiapkan strategi penggunaan dana-dana yang dihimpunnya sesuai dengan rencana alokasi berdasarkan kebijakan yang telah 
digariskan dengan tujuan untuk mencapai tingkat profitabilitas yang cukup dengan tingkat rasio yang rendah dan untuk mempertahankan kepercayaan masyarakat

Alokasi penggunaan dana bank syariah pada dasarnya dapat dibagi dalam dua bagian penting dari aktiva bank, yaitu; aktiva yang menghasilkan dan aktiva yang tidak menghasilkan. ${ }^{19}$ Aktiva yang dapat menghasilkan adalah asset bank yang digunakan untuk menghasilkan pendapatan. Asset ini disalurkan dalam bentuk investasi yang terdiri atas:

a. Pembiayaan berdasarkan prinsip bagi hasil (mudārabah)

b. Pembiayaan berdasarkan prinsip penyertaan (mushärakah)

c. Pembiayaan berdasarkan prinsip jual beli (al-bai')

d. Pembiayaan berdasarkan prinsip sewa (ijārah dan ijārah wa iqtinā/ijārah muntahiah bi tamlīk)

e. Surat-surat berharga syariah dan investasi lainnya.

Sedangkan aktiva yang tidak memberikan penghasilan adalah: aktiva dalam bentuk tunai, pinjaman (qard), dan penanaman dana dalam aktiva tetap dan inventaris.

Secara skematis sumber dan penggunaan dana berdasarkan pendapatan pusat Pengumpulan Dana (pool of find approach) dapat digambarkan seperti pada diagram dibawah ini:

Gambar 2:

Sumber dan penggunaan dana berdasarkan pendekatan pusat pengumpulan dana (pool of fund approach)

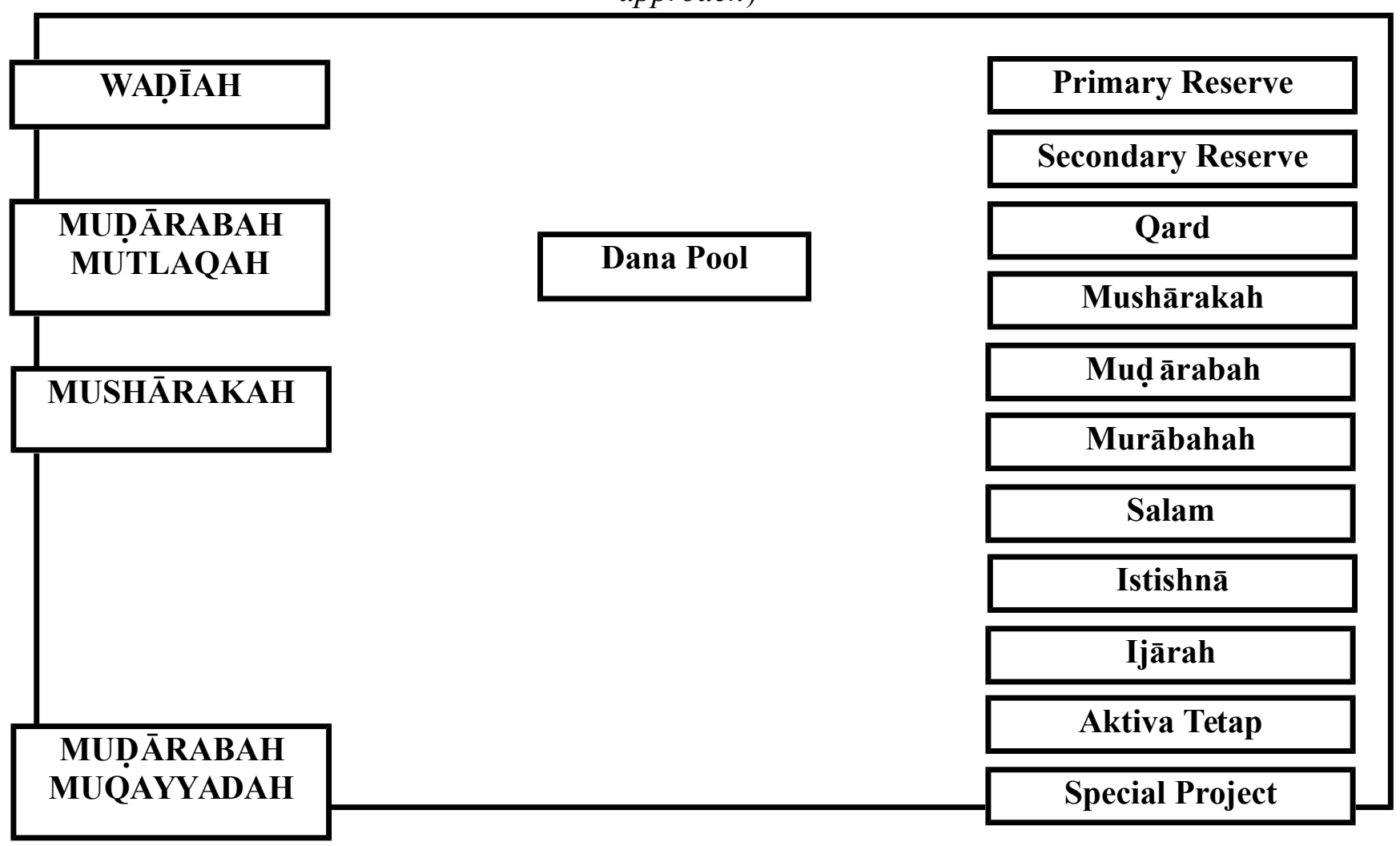


Sumber: Muhammad, Manajemen Bank Syariah (Yogyakarta:UPP AMP YKPN,2002),

Secara khusus, sumber penerimaan dana dapat dialokasikan pada sisi-sisi pembiayaan. Secara skematis diagram sumber dan penggunaan dana berdasarkan pendekatan alokasi aktiva. (assets allocation approach) dapat digambarkan sebagai berikut:

Gambar : 3

Sumber dan Penggunaan Dana Berdasarkan Assets Allocation Approach

Sumber : Muhammad," Manajemen Bank Syariah,” (Yogyakarta: UPP AMP YKPN, 2002), 24.

\section{Penutup}

Permasalahan yang dihadapi perbankan Islam sesungguhnya jika mau jujur, masih banyak permasalahan yang dihadapi oleh Perbankan Syariah. Adapun beberapa problematika yang muncul seiring dengan berkembangnya industri perbankan Syariah dapat kita kategorikan pada beberapa masalah diantaranya adalah:

Pertama, adalah kurangnya deposito. Perbankan yang beroperasi secara syariah tidak dapat menerima simpanan dari orang-orang yang ingin mendapat keuntungannya tanpa menanggung resiko apapun. Kedua, likuiditas berlebihan (excessive liquidity), tentu saja bank Islam akan lebih cenderung mempertahankan rasio yang tinggi antara uang tunai dengan simpanannya, bila dihandingkan dengan perbankan konvensional. Ini dilakukan untuk mengantisipasi penarikan rekening 
tabungan yang dilakukan nasabah sewaktu-waktu tanpa pemberitahuan terlebih dahulu. Kemudian tidak semua nasabah bank Islam yang potensial menyetujui meminjamkan uangnya berdasarkan prinsip mushawarah atau kemitraan. Pada umumnya nasabah lebih senang meminjam dana atas dasar mudarabah, atau bahkan meminjam dari bank konvensional dengan system bunga. Masalah yang ketiga, adalah problem ketika biaya dan profitabilitas. Bank Islam bekerja dengan aturan yang sangat ketat dan memilih investasi yang halal dan sesuai Syariah saja.Implikasinya adalah bank Islam harus melakukan supervisi dan terkadang mengelola secara langsung operasional suatu proyek yang didanainya.

Masalah keempat yang dihadapi selanjutnya adalah masalah pendanaan pinjaman untuk konsumsi. Bank Islam terkadang kesulitan untuk memberi pinjaman yang bertujuan konsumtif. Hal ini disebabkan oleh masih terbatasnya dana yang dapat dipinjamkan tanpa memperoleh keuntungan. Masalah yang kelima adalah masih minimnya sumberdaya manusia yang memahami secara komprehensif segala hal yang berkaitan dengan industri perbankan Syariah. Dan masalah keenam yang dihadapi kalangan perbankan syariah adalah belum maksimalnya institusi undang-undang yang menjadi payung hukum bagi keseluruhan aktivitas perbankan Islam. ${ }^{12}$

Pada tahun 2004 kinerja perbankan syariah akan tergantung pada pemberian pembiayaan kepada nasabah. Namun, harus diakui bahwa bank-bank syariah, seperti halnya bank konvensional lainnya, tidak mudah mencari nasabah yang potensial, apalagi pasar yang dibidik oleh bank syariah hampir sama dengan bank konvensional, terutama yang bergerak di pasar ritel. Untuk itu, bank-bank syariah harus lebih mempercepat distribusi kredit dengan kualitas yang baik. ${ }^{13}$

Dengan permasalahan tersebut, sudah barang tentu manajemen bank syariah harus tetap ditingkatkan dan lebih kembangkan agar dapat memenuhi kebutuhan manusia seluruhnya tanpa memandang agama, suku, ras dan sebagainya, sehingga masyarakat muslim lebih percaya dengan produk yang lahir dari ajaran sendiri

12 Irfan Syauqi Beik, Problematika Perbankan Syariah, (Kajian Ekonomi, http://www2. Pesantren virtual.com, Rabu, 8 September 2004). Februari 2004)

13 Rubrik Perbankan: "Bank Syariah Mulai Kelebihan Muatan", (Kompas: Kamis 26 
ketimbang produk kapitalis.

\section{Daftar Pustaka}

Adnan, Muhammad Akhyar, "Beberapa Issue di Sekitar Pengembangan Lembaga Keuangan Berdasarkan Syariah", makalah disajikan dalam Seminar dan Talk Show "Peran Ulama dalam Sosialisasi Lembaga Keuangan Syariah", 15 Maret 1999.

Antonio. Muhammad Syafi'i, Bank Svari'ah dari Teori ke Praktek (Jakarta: GemaInsani Press, 2001).

Arifin, Zaenul, Dasar-dasar Manajemen Bank Syariah (Jakarta: Alvabet, 2002).

Beik, Irfan Syauqi, Problematika Perbankan Syariah (Kajian Ekonomi, http:Uwww2. pesantrenvirtual.com, Rabu. 8 September 2004).

Hafifuddin, Didin, Manajemen Syariah (Jakarta: Gema Insani Press,2003).

Kompas, Bank Syariah Mulai Kelebihan Muatan (Kamis, 26 Februari2004).

Muhammad, Manajemen Bank Syar'ah (Yogyakarta: UPP AMP YKPN,2002).

Nabahan, M. Faruq an-, Sistem Ekonomi Islam: Pilihan Setelah kegagalan Sistem Kapitalis dan sosialis, Terj. Muhadi Zainuddin. (Yogyakarta: UII Press, 2000).

Rini, Mike, Bank.Syariah (Dikutip dari C13N CyberSHOPPING).

Saeed, Abdullah, Menyoal Bank Syariah; Kritik Alas Interpretasi Bunga Bank Kaum neo-Revivalis, terj.A rif Maftuhin. (Jakarta: Paramadina, 2004).

Tim Pengembangan Perbankan Syariah, Institut Bankir Indonesia, Konsep, Produk, dan Implementasi Operasional Bank Syariah (Jakarta: Djambatan, 2001). 
